\title{
Lignicolous freshwater fungi in China III: Three new species and a new record of Kirschsteiniothelia from northwestern Yunnan Province
}

\author{
Bao DF ${ }^{1,2,3}$, Luo $\mathrm{ZL}^{1,2}$, Liu JK ${ }^{4}$, Bhat $\mathrm{DJ}^{5}$, Sarunya $\mathrm{N}^{3}$, Li WL ${ }^{1,6}, \mathrm{Su}_{\mathrm{HY}}{ }^{1^{*}}$ and \\ Hyde KD ${ }^{2}$
}

${ }^{1}$ College of Agricultural \& Biological Sciences, Dali University, Dali 671003, Yunnan, China

${ }^{2}$ Center of Excellence in Fungal Research, Mae Fah Luang University, Chiang Rai 57100, Thailand

${ }^{3}$ Department of Entomology and Plant Pathology, Faculty of Agriculture, Chiang Mai University, Chiang Mai 50200,

Thailand

${ }^{4}$ Guizhou Key Laboratory of Agricultural Biotechnology, Guizhou Academy of Agricultural Sciences, Guiyang 550006, Guizhou, China

${ }^{5}$ 128/1-J, Azad Housing Society, Curca, Goa Velha-403108, India

${ }^{6}$ College of Basic Medicine, Dali University, Dali 671003, Yunnan, China

Bao DF, Luo ZL, Liu JK, Bhat DJ, Sarunya N, Li WL, Su HY, Hyde KD 2018 - Lignicolous freshwater fungi in China III: New species and record of Kirschsteiniothelia from northwestern Yunnan Province. Mycosphere 9(4), 755-768, Doi 10.5943/mycosphere/9/4/4

\begin{abstract}
The diversity of lignicolous freshwater fungi of China is currently being studied. In this paper, fresh collections of Kirschsteiniothelia species from submerged wood in northwestern Yunnan Province, China, were reported. The phylogenetic analyses of combined ITS, LSU and SSU sequence data placed the isolates of the taxa within the family Kirschsteiniotheliaceae. Three new species, Kirschsteiniothelia aquatica, K. cangshanensis and $K$. fluminicola are introduced, based on their distinct morphology and evidences from molecular phylogeny. A detailed description of Kirschsteiniothelia rostrata, a new record for China is provided.
\end{abstract}

Key words - 3 new species - Asexual morphs - Kirschsteiniotheliaceae - Phylogeny - Taxonomy

\section{Introduction}

The genus Kirschsteiniothelia was introduced by Hawksworth (1985a) with K. aethiops (Berk. \& M.A. Curtis) D. Hawksw. as the type. Kirschsteiniothelia species are characterized by superficial, globose or subglobose, dark brown to black ascomata, fissitunicate, cylindrical-clavate asci, and dark brown, septate ascospores, with or without a mucilagenous sheath (Hawksworth 1985a, Boonmee et al. 2012, Hyde et al. 2013, Mehrabi et al. 2017).

Kirschsteiniothelia aethiops has been linked with the asexual genus Dendryphiopsis (Hughes 1953, Hawksworth 1985a, Boonmee et al. 2012, Hyde et al. 2013, Wijayawardene et al. 2017a, b). The genus Dendryphiopsis is characterized by macronematous, branched or unbranched, erect, septate, brown to dark brown conidiophores; terminal, determinate, monophialidic, conidiogenous cells; and cylindric-obclavate, septate, pale brown to dark brown conidia (Hyde et al. 2013, Su et al. 2016). Based on morphology and molecular data, Schoch et al. (2009) established the sexual and asexual connection of Kirschsteiniothelia (Schoch et al. 2009, Boonmee et al. 2012, Hyde et al. 2013, Wijayawardene et al. 2014). Furthermore, Boonmee et al. (2012) showed that K. aethiops 
grouped with D. atra (Corda) S. Hughes, the type species of Dendryphiopsis based on phylogenetic analysis. Wijayawardene et al. (2014) therefore, proposed the synonymy of Dendryphiopsis atra under Kirschsteiniothelia atra (Corda) D. Hawksw.

Kirschsteiniothelia was previously placed in the family Pleosporaceae (Hawksworth 1985a, Barr 1987). Barr (1993) thought that Kirschsteiniothelia should be placed in Pleomassariaceae, based on the asexual morph connection and morphology. Subsequently, Schoch et al. (2006) showed that $K$. aethiops does not cluster with Pleosporaceae in their phylogenetic tree, thus they considered that the genus Kirschsteiniothelia should be transferred to a new family. Boonmee et al. (2012) established a new family Kirschsteiniotheliaceae to accommodate Kirschsteiniothelia in the class Dothideomycetes, based on morphological characters and phylogenetic analysis. In addition, K. maritima (Linder) D. Hawksw. was found to group in the Mytilinidiaceae clade, as a sister group to Mytilinidion species. However, Kirschsteiniothelia maritima differed from Mytilinidion in morphology and in its marine habitat (Hawksworth 1985b, Kohlmeyer \& Kohlmeyer 1979, Figueira \& Barata 2007, Suetrong et al. 2009). Therefore, Boonmee et al. (2012) introduced a new genus, Halokirschsteiniothelia, to accommodate K. maritima. Kirschsteiniothelia elaterascus clustered in the same clade as Morosphaeria, and this species was transferred to Morosphaeria based on the phylogenetic analysis of Boonmee et al. (2012).

We are carrying out a survey on the diversity of lignicolous freshwater fungi along a northsouth gradient in the Asian region (Hyde et al. 2016) and this is the third in a series of papers on these fungi from China (Li et al. 2017, Luo et al. 2018). In this study, we collected four sporidesmium-like hyphomycete taxa from submerged wood in streams and rivers in the west to northwest of Yunnan Province, China. In placing hyphomycetes in a natural classification, it is essential to obtain sequence data, as many morphologically similar taxa are shown to be unrelated (Shenoy et al. 2007, Su et al. 2016). We therefore used phylogenetic analyses to establish our new taxa with other species of Kirschsteiniothelia. In this paper, three new species, namely Kirschsteiniothelia aquatica, K. cangshanensis and $K$. fluminicola are introduced based on morphological characters and phylogenetic analyses. Newly generated molecular data, descriptions and illustrations of Kirschsteiniothelia rostrata are also provided.

\section{Materials \& methods}

\section{Isolation and morphology}

Specimens of submerged wood were collected from Cangshan Mountain, Gaoligongshan Mountain, Jingsha River and Du long River, in the west of northwest of Yunnan, China. The process of morphological studies is following Luo et al. (2018). The morphological observations were made using a Motic SMZ 168 Series stereomicroscope and photographed by a Nikon E80i microscope-camera system. Measurements were made with the Tarosoft (R) Image Frame Work (Liu et al. 2010).

Single spore isolations were made to obtain pure cultures following the description by Chomnunti et al. (2014). Germinating spores were transferred to fresh PDA or MEA plates and incubated at room temperature 2-4 weeks. The cultures are deposited in Mae Fah Luang University Culture Collection (MFLUCC), Specimens (dry wood material with fungal material) are deposited in the herbarium of Mae Fah Luang University (MFLU).

\section{DNA extraction, PCR amplification, and sequencing}

Fungal mycelium $(500 \mathrm{mg})$ was scraped from surface of colonies grown on PDA plate or MEA plate, transferred into a $1.5 \mathrm{~mL}$ centrifuge tube and ground using liquid nitrogen. The EZ geneTM fungal gDNA kit (GD2416) was used to extract DNA according to the manufacturer's instructions. The primers ITS5/ITS4, LROR/LR5, NS1/NS4 were used for ITS, LSU and SSU gene regions respectively. The PCR mixture was including $12.5 \mu \mathrm{L}$ of $2 \times$ Power Taq PCR MasterMix (a premix and ready to use solution, including 0.1 Units/ $\mu$ Taq DNA Polymerase, $500 \mu \mathrm{m}$ dNTP Mixture each (dATP, dCTP, dGTP, dTTP), $20 \mathrm{mM}$ Tris- $\mathrm{HCl}$ pH 8.3, 100MmKCl, $3 \mathrm{mMMgCl}$, 
stabilizer and enhancer), $1 \mu \mathrm{L}$ of each primer $(10 \mu \mathrm{M}), 1 \mu \mathrm{L}$ genomic DNA extract and $9.5 \mu \mathrm{L}$ deionized water. PCR thermal cycles for the amplification of the gene regions were as described in $\mathrm{Su}$ et al. (2015). PCR products were purified using minicolumns, purification resin and buffer according to the manufacturer sprotocols (Amersham product code: 27-9602-01). The sequencing reactions were carried out by Shanghai Sangon Biological Engineering Technology and Services Co., Shanghai, P.R. China.

\section{Phylogenetic analysis}

Raw sequences were assembled with Sequencher 4.9 for Windows (Gene Codes Corp., Ann Arbor, MI, USA). The consensus sequences were initially aligned using MAFFTv.7 (http://mafft.cbrc.jp/alignment/server/) (Katoh \& Standley 2013) and optimised manually when needed.

The phylogeny website tool "ALTER" (Glez-Peña et al. 2010) was used to transfer the alignment fasta file to Phylip format for RAxML analysis. Maximum likelihood (ML) analysis was performed at the CIPRES Science Gateway v.3.3 (http:// www.phylo.org/portal2/, Miller et al. 2010) using RAxML v. 8.2.8 as part of the "RAxML-HPC BlackBox" tool (Stamatakis 2006, Stamatakis et al. 2008). All free model parameters were estimated by RAxML with ML estimates of 25 per site rate categories. The final ML search was conducted using the GTRGAMMA + I model. The best scoring tree was selected with a final likelihood value of -16566.464053. RAxML bootstrap support values greater than $75 \%$ are given above at the branches (Fig. 1).

Bayesian analyses were performed by using MrBayes v3.0b4 (Ronquist \& Huelsenbeck 2003). The model of evolution was estimated by using MrModeltest 2.2 (Nylander 2004). Posterior probabilities (PP) (Rannala \& Yang 1996) were performed by Markov Chain Monte Carlo Sampling (BMCMC) in MrBayes v. 3.0b4 (Liu et al. 2012). Six simultaneous Markov Chains were run for one million generations, and trees were sampled every100th generation (Resulting 10,000 total trees) (Cai et al. 2005). The first 2000 trees representing the burn-in phase of the analyses were discarded and the remaining 8000 (post burning) trees used for calculating posterior probabilities (PP) in the majority rule consensus tree (Cai et al. 2006, Liu et al. 2012).

Table 1 Isolates and sequences used in this study and newly generated sequences are indicated in bold

\begin{tabular}{llccc}
\hline \multirow{2}{*}{ Taxon } & \multirow{2}{*}{ Strain number } & GTS & LSU & SSU \\
\cline { 3 - 5 } & & EU940180 & EU940104 & EU940031 \\
\hline Acrospermum adeanum & M133 & EU940161 & EU940084 & EU940012 \\
Acrospermum compressum & M151 & EU940162 & EU940085 & EU940013 \\
Acrospermum gramineum & M152 & - & EF175651 & EF175630 \\
Aliquandostipite crystallinus & R 76-1 & - & GU301796 & - \\
Aliquandostipite khaoyaiensis & CBS 118232 & - & DQ678046 & DQ677996 \\
Dendryphiopsis atra & AFTOL-ID 273 & - & GU479799 & GU479766 \\
Dyfrolomyces rhizophorae & JK5456A & - & KC692156 & KC692155 \\
Dyfrolomyces tiomanensis & NTOU3636 & - & GU327717 & JN887382 \\
Flavobathelium epiphyllum & MPN67 & AY916464 & AY856881 & AY856928 \\
Helicomyces roseus & CBS 283.51 & KY320523 & KY320540 & - \\
Helicomyces roseus & MFLUCC 15-0343 & JN942354 & EF175655 & EF175632 \\
Jahnula aquatica & R68-1 & JN942353 & EF175657 & EF175635 \\
Jahnula bipileata & F49-1 & JN942349 & EF175661 & EF175639 \\
Jahnula sangamonensis & A402-1B & - & EF175664 & EF175643 \\
Jahnula seychellensis & SS 2113.2 & - & AY016361 & AY016344 \\
Kirschsteiniothelia aethiops & CBS 109.53 & & & \\
\hline
\end{tabular}


Table 1 Continued.

\begin{tabular}{llccc}
\hline \multirow{2}{*}{ Taxon } & \multirow{2}{*}{ Strain number } & \multicolumn{2}{c}{ GenBank accession number } \\
\cline { 2 - 5 } K. aethiops & MFLUCC 16-1104 & MH182583 & MH182589 & MH182615 \\
K. aethiops & S-783 & MH182586 & MH182595 & MH182617 \\
K. aethiops & MFLUCC 15-0424 & KU500571 & KU500578 & KU500585 \\
K. aquatica & MFLUCC 17-1685 & MH182587 & MH182594 & MH182618 \\
K. arasbaranica & IRAN 2509C & KX621986 & KX621987 & KS621988 \\
K. arasbaranica & IRAN 2508C & KX621983 & KX621984 & KX621985 \\
K. cangshanensis & MFLUCC 16-1350 & MH182584 & MH182592 & - \\
K. fluminicola & MFLUCC 16-1263 & MH182582 & MH182588 & - \\
K. lignicola & MFLUCC 10-0036 & HQ441567 & HQ441568 & HQ441569 \\
K. phoenicis & MFLUCC 18-0216 & MG859978 & MG860484 & MG859979 \\
K. rostrata & MFLUCC15-0619 & KY697280 & KY697276 & KY697278 \\
K. rostrata & MFLUCC 16-1124 & - & MH182590 & - \\
K. submersa & HA-2016 & KU500570 & KU500577 & KU500584 \\
K. submersa & S-481 & - & MH182591 & MH182616 \\
K. submersa & S-601 & MH182585 & MH182593 & - \\
K. tectonae & MFLUCC 12-0050 & KU144916 & KU764707 & - \\
K. thujina & JF13210 & KM982716 & KM982718 & KM982717 \\
Phyllobathelium anomalum & MPN 242 & - & GU327722 & JN887386 \\
Pleospora herbarum & CBS191.86 & NR111243 & GU238160 & GU238232 \\
Pleospora herbarum & MFLUCC 14-0920 & KY659560 & KY659563 & KY659567 \\
Tubeufia helicomyces & CBS 271.52 & AY916461 & AY856887 & AY856933 \\
Tubeufia javanica & MFLUCC 12-0545 & KJ880034 & KJ880036 & KJ880035 \\
Tubeufia paludosa & CBS 120503 & - & GU301877 & GU296203 \\
\hline & & & &
\end{tabular}

\section{Results}

\section{Phylogenetic analyses}

The combined sequence alignment comprised 39 taxa (Table 1), with Pleospora herbarum (CBS 19186, MFLUCC 14-0920) as the outgroup taxa, with 2248 characters including gaps. The result of maximum likelihood (ML) analysis based on combined ITS, LSU and SSU sequence data consisted of six families (Acrospermaceae, Aliquandostipitaceae, Dyfrolomycetaceae, Strigulaceae, Kirschsteiniotheliaceae and Tubeufiaceae) within the Dothideomycetes (Fig. 1). The phylogenetic analyses showed that all the new strains cluster in the family Kirschsteiniotheliaceae with high support (100\% ML and 1.00 PP). Three newly generated isolates of Kirschsteiniothelia species and Kirschsteiniothelia phoenicis formed a monotypic lineage at the basal position of the family Kirschsteiniotheliaceae with strong support (100\% ML and 1.00 PP). Four isolates in this lineage formed distinct clades which can be recognized as four different phylogenetic species and of which three were introduced as new species, namely Kirschsteiniothelia aquatica, K. cangshanensis and K. fluminicola.

\section{Taxonomy}

In this section, we introduce three new species, Kirschsteiniothelia aquatica, $K$. cangshanensis and $K$. fluminicola with descriptions and illustrations, and also provide descriptions and illustrations for $K$. rostrata which is a new record for China. 


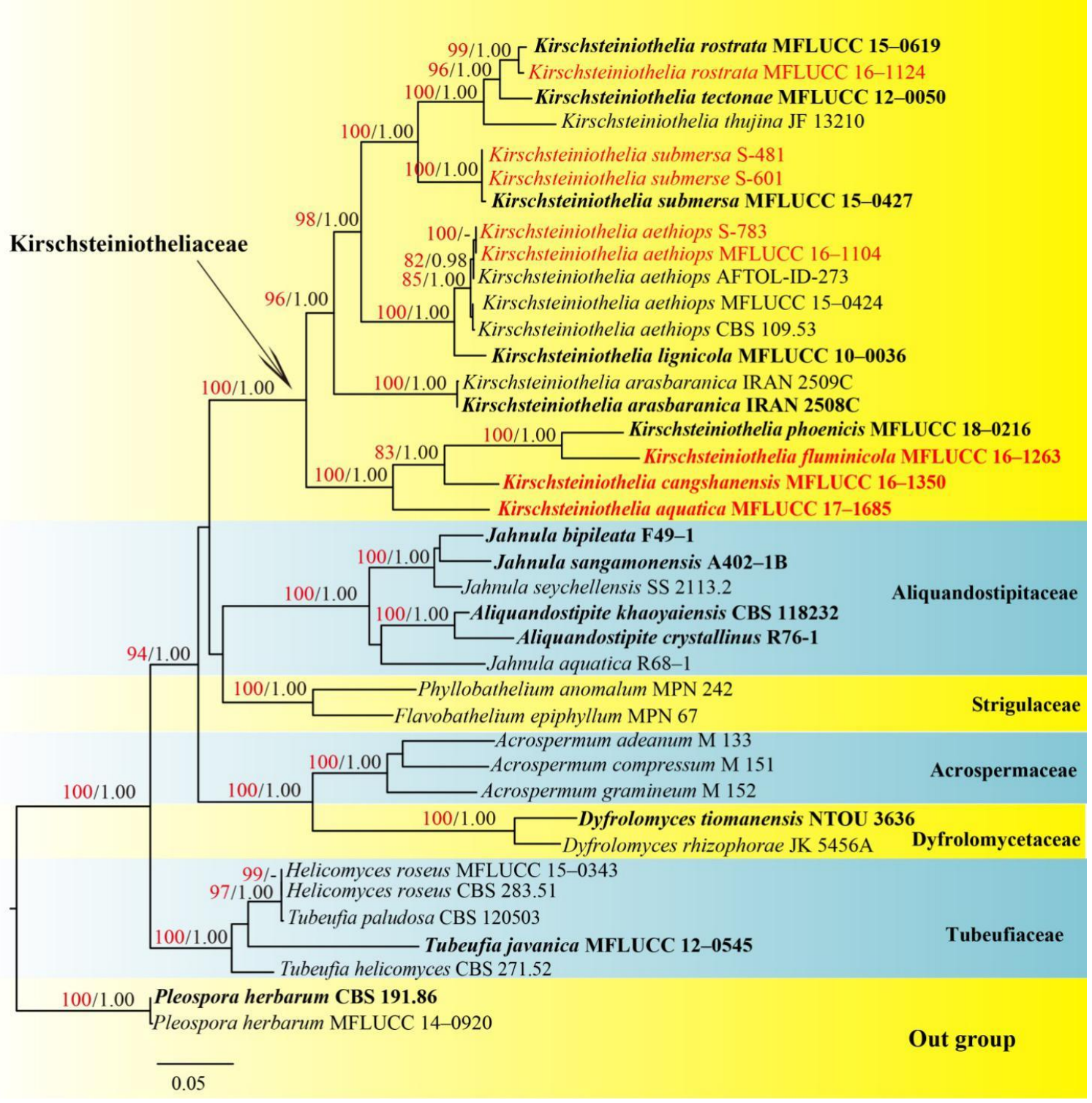

Figure 1 - Phylogenetic tree generated from maximum likelihood (ML) analysis based on combined ITS, LSU and SSU sequence data for some selected families within the Dothideomycetes. Bootstrap support values for maximum likelihood (ML) greater than $75 \%$ and Bayesian posterior probabilities (PP) greater than 0.95 are given above the nodes. Newly generated sequences are indicated in red and ex-type strains are in bold.

Kirschsteiniothelia aquatica Z.L. Luo, K.D. Hyde \& H.Y. Su, sp. nov.

Fig. 2

Index Fungorum number: IF554783; Facesoffungi number: FoF04690

Holotype - MFLU 18-1077

Etymology - Referring to the aquatic habitat of this fungus.

Saprobic on submerged decaying wood. Sexual morph: Undetermined. Asexual morph: Colonies effuse on natural substrate, hairy, dark brown. Mycelium partly superficial, partly immersed in the substrate, composed of septate, branched, smooth-walled hyphae. Conidiophores macronematous, mononematous, erect, straight or flexuous, unbranched, thick-walled, dark brown, septate, cylindrical, $114-151 \mu \mathrm{m}(\bar{x}=132.5 \mu \mathrm{m}, \mathrm{SD}=18.5, \mathrm{n}=10)$ long, 7-8 $\mu \mathrm{m}(\bar{x}=7.5 \mu \mathrm{m}$, $\mathrm{SD}=0.5, \mathrm{n}=10$ ) wide. Conidiogenous cells monoblastic, holoblastic, integrated, determinate or percurrently proliferating, terminal, dark brown, cylindrical. Conidia acrogenous, solitary, dry, straight or slightly curved, subhyaline and rounded at apex, truncate, thick-walled and dark brown at base, smooth, 35-46 $\mu \mathrm{m}(\bar{x}=40.5 \mu \mathrm{m}, \mathrm{SD}=5.5, \mathrm{n}=20)$ long, 7.5-8.5 $\mu \mathrm{m}(\bar{x}=8 \mu \mathrm{m}, \mathrm{SD}=0.5$, $\mathrm{n}=20$ ) wide, sometimes percurrently proliferate at broken ends. 
Material examined - CHINA, Yunnan Province, saprobic on decaying wood submerged in a stream in Cangshan Mountain, July 2015, H.W. Shen, XP H 1-12-1, S-708 (MFLU 18-1077, holotype), ex-type culture, MFLUCC 17-1685.

Notes - This fungus was collected from Cangshan Mountain, Yunnan Province, China. Kirschsteiniothelia aquatica resembles $K$. cangshanensis and $K$. fluminicola in having macronematous, straight or flexuous, unbranched, thick-walled, septate conidiophores, and solitary, septate, conidia. However, $K$. aquatica differs from $K$. cangshanensis in having longer conidiophores (114-151 $\mu \mathrm{m}$ vs $105.5-135.5 \mu \mathrm{m})$, and subhyaline, truncate, thick-walled conidia, rounded at apex, and dark brown at base. Kirschsteiniothelia aquatica differs from $K$. fluminicola in having shorter and thinner conidiophores $(114-151 \times 7-8 \mu \mathrm{m}$ vs $209-286 \times 7-9 \mu \mathrm{m})$. They are also phylogenetically distinct (Fig. 1).

Kirschsteiniothelia cangshanensis Z.L. Luo, D.F. Bao, K.D. Hyde \& H.Y. Su, sp. nov.

Fig. 3

Index Fungorum number: IF554784; Facesoffungi number: FoF04691

Holotype - MFLU 17-1426

Etymology - Referring the fungus collected from Cangshan Mountain.

Saprobic on submerged decaying wood. Sexual morph: Undetermined. Asexual morph: Colonies effuse, scattered, hairy, pale brown to brown. Mycelium mostly immersed, composed of pale brown to brown, septate, branched hyphae. Conidiophores macronematous, mononematous, erect, pale brown, septate, unbranched, cylindrical, percurrent, straight or flexuous, 105.5-135.5 $\mu \mathrm{m}(\bar{x}=120.5 \mu \mathrm{m}, \mathrm{SD}=15, \mathrm{n}=20)$ long, $6-8 \mu \mathrm{m}(\bar{x}=7 \mu \mathrm{m}, \mathrm{SD}=1, \mathrm{n}=20)$ wide. Conidiogenous cells monoblastic, integrated, terminal, determinate, pale brown, cylindrical, percurrently proleferating. Conidia solitary, dry, obclavate, septate, straight or slightly curved, pale brown to brown, with a gelatinous sheath at apex, $33-43 \mu \mathrm{m}(\bar{x}=38 \mu \mathrm{m}, \mathrm{SD}=5, \mathrm{n}=20)$ long, $7.5-8.5 \mu \mathrm{m}(\bar{x}=8 \mu \mathrm{m}, \mathrm{SD}=0.5$, $\mathrm{n}=20$ ) wide.

Material examined - CHINA, Yunnan Province, saprobic on decaying wood submerged in Jinsha River, April 2015, Z.L. Luo, S-561, (MFLU 17-1426, holotype), ex-type culture, MFLUCC $16-1350$.

Notes - Kirschsteiniothelia cangshanensis shares similar characters with K. fluminicola in having macronematous, unbranched, cylindrical, septate, conidiophores and solitary, obclavate, septate, conidia. However, $K$. cangshanensis differs from $K$. fluminicola in having a gelatinous rounded sheath at the apex of shorter and thinner conidia $(33-43 \times 7.5-8.5 \mu \mathrm{m}$ vs $47.5-86.5 \times 8-10$ $\mu \mathrm{m})$.

Kirschsteiniothelia fluminicola Z.L. Luo, K.D. Hyde \& H.Y. Su, sp. nov.

Fig. 4

Index Fungorum number: IF555283; Facesoffungi number: FoF04692

Holotype - MFLU 17-1427

Etymology - Referring to the fungus living in a stream.

Saprobic on submerged decaying wood. Sexual morph: Undetermined. Asexual morph: Colonies effuse on natural substrate, hairy, dark brown. Mycelium immersed, dark brown to black, composed of unbranched, septate hyphae. Conidiophores erect, straight or flexuous, septate, smooth, cylindrical, dark brown to black, unbranched, percurrent, 209-286 $\mu \mathrm{m}(\bar{x}=247.5 \mu \mathrm{m}$, $\mathrm{SD}=38.5, \mathrm{n}=20)$ long, 7-9 $\mu \mathrm{m}(\bar{x}=8 \mu \mathrm{m}, \mathrm{SD}=1, \mathrm{n}=20)$ wide. Conidiogenous cells monoblastic, terminal, indeterminate, percurrently proliferating, cylindrical, dark brown. Conidia solitary to short-catenate, obclavate, rostrate, truncate at base, slender and rounded at apex, aseptate when immature, multi-septate at maturity, subhyaline to dark brown, with conspicuous, spherical guttules in almost all cells, 47.5-86.5 $\mu \mathrm{m}(\bar{x}=67 \mu \mathrm{m}, \mathrm{SD}=19.5, \mathrm{n}=20)$ long, $8-10 \mu \mathrm{m}(\bar{x}=9 \mu \mathrm{m}$, $\mathrm{SD}=1, \mathrm{n}=20$ ) wide.

Material examined - CHINA, Yunnan Province, saprobic on decaying wood submerged in Dulong River, May 2015, Z.L. Luo, S-315, (MFLU 17-1427, holotype), ex-type culture, MFLUCC 16-1263. 
Notes - Kirschsteiniothelia fluminicola is introduced here based on distinct morphology and molecular data. Kirschsteiniothelia fluminicola is grouped in the family Kirschsteiniotheliaceae and it is sister to K. phoenicis (MFLUCC18-0216) as in Fig 1. K. fluminicola can be distinguished from other species in having short-catenate, slender conidia rounded at apex and multi-septate at maturity.
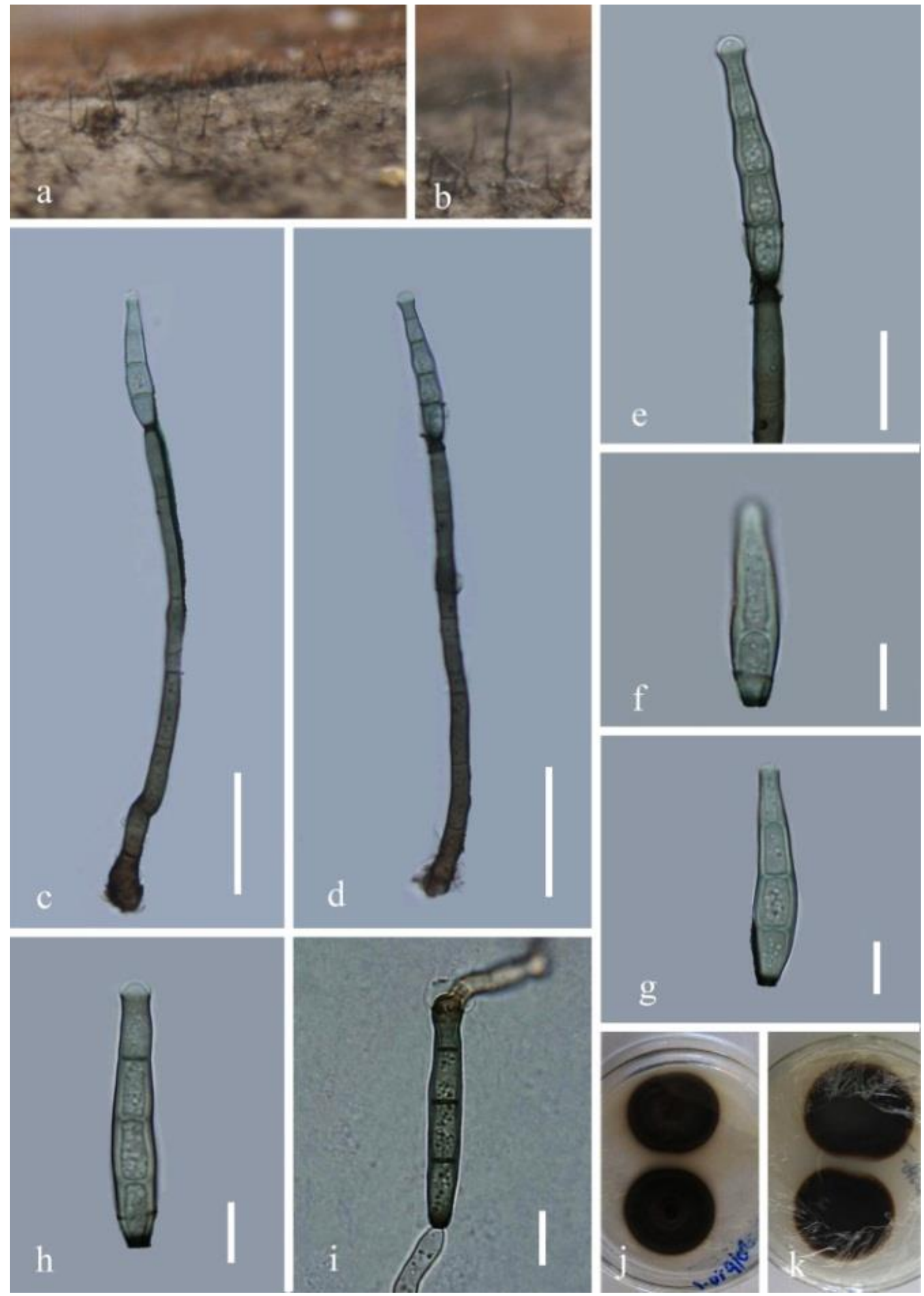

Figure 2 - Kirschsteiniothelia aquatica (MFLU 18-1077, holotype) a, b Colonies on wood. $\mathrm{c}, \mathrm{d}$ Conidiophore with conidia. e Conidiogenous cells and conidia. $\mathrm{f}-\mathrm{h}$ conidia. i Germinating conidium. j, k Culture on PDA from surface and reverse. Scale bars: $\mathrm{c}, \mathrm{d}=40 \mu \mathrm{m}, \mathrm{e}=30 \mu \mathrm{m}$, $\mathrm{f}-\mathrm{i}=10 \mu \mathrm{m}$. 

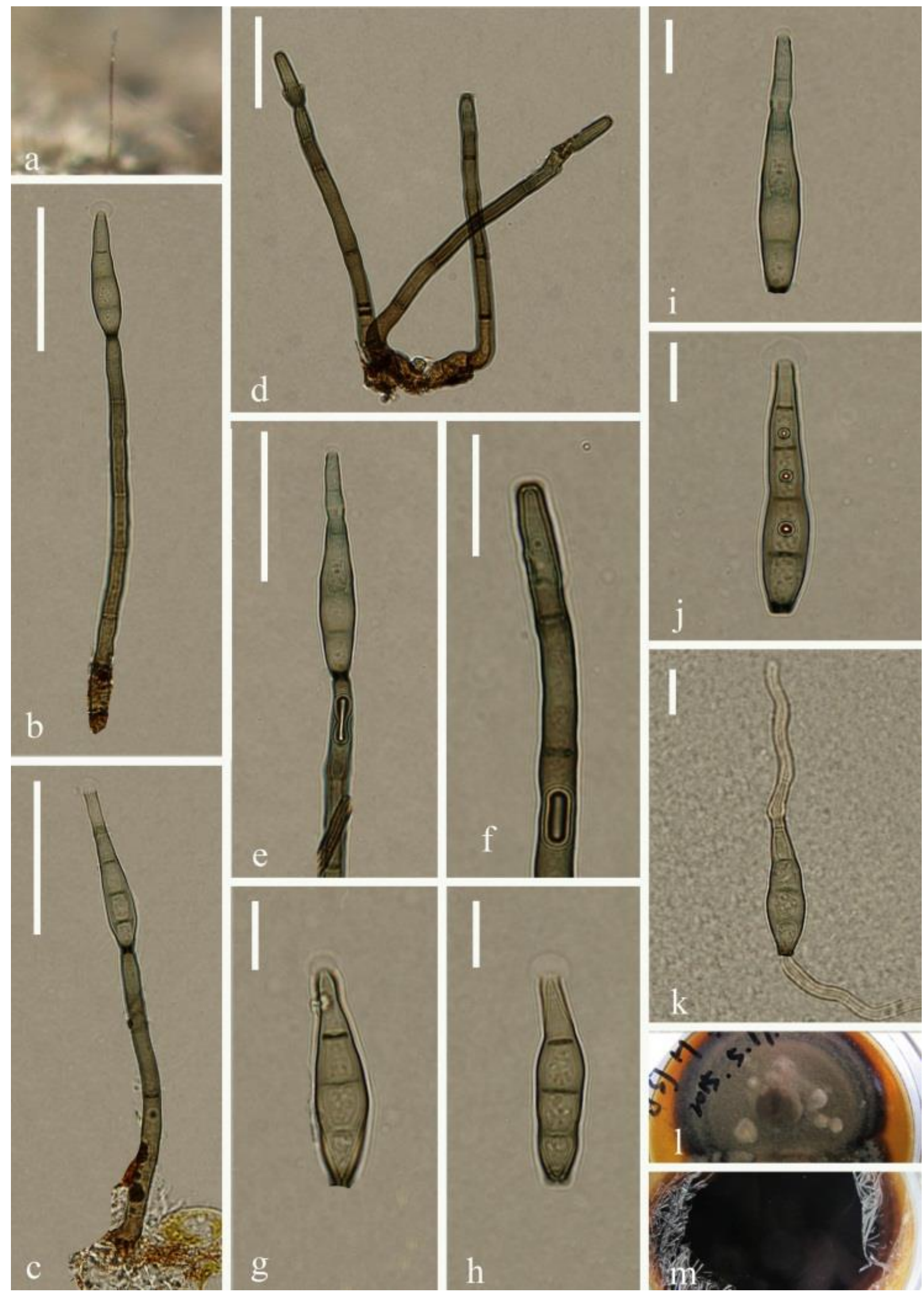

Figure 3 - Kirschsteiniothelia cangshanensis (MFLU 17-1426, holotype) a Colonies on wood. $\mathrm{b}$, c Conidiophore with conidia. d Conidiophore. $\mathrm{e}-\mathrm{f}$ Conidiogenous cells and conidia. $\mathrm{g}-\mathrm{j}$ Conidia. $\mathrm{k}$ Germinating conidium. $1, \mathrm{~m}$ Culture on MEA from surface and reverse. Scale bars: $\mathrm{b}, \mathrm{c}=40 \mu \mathrm{m}$, $\mathrm{d}, \mathrm{e}=30 \mu \mathrm{m}, \mathrm{f}=15 \mu \mathrm{m}, \mathrm{g}-\mathrm{k}=10 \mu \mathrm{m}$. 

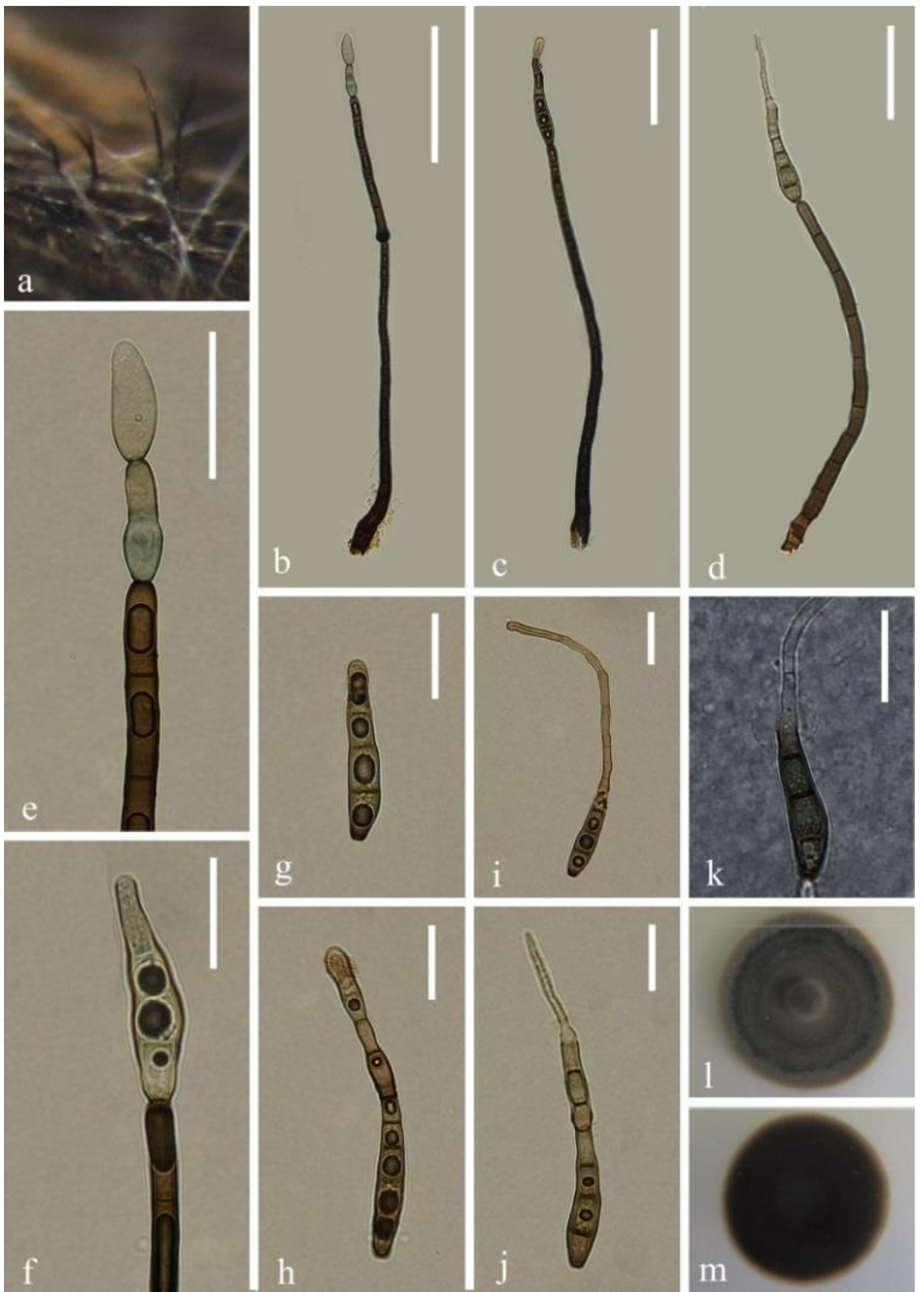

Figure 4 - Kirschsteiniothelia fluminicola (MFLU 17-1427, holotype) a Colonies on wood. $\mathrm{b}-\mathrm{d}$ Conidiophore with conidia. e, f Conidiogenous cells with conidia. $\mathrm{g}-\mathrm{j}$ Conidia. $\mathrm{k}$ Germinating conidium. $1, \mathrm{~m}$ Culture on PDA from surface and reverse. Scale bars: $\mathrm{b}=40 \mu \mathrm{m}, \mathrm{c}, \mathrm{d}=50 \mu \mathrm{m}$, $\mathrm{e}=30 \mu \mathrm{m}, \mathrm{f}-\mathrm{k}=20 \mu \mathrm{m}$.

Kirschsteiniothelia rostrata J. Yang \& K.D. Hyde, Fungal Diversity 87: 45 (2017)

Fig. 5

Index Fungorum number: IF552909

Saprobic on submerged decaying wood. Sexual morph: Undetermined. Asexual morph: Colonies effuse on natural substrate, scattered, hairy, dark brown to black. Mycelium partly immersed, partly superficial on the substrate, composed of pale brown, septate, branched hyphae. 
Conidiophores macronematous, mononematous, solitary, wide and slightly swollen at base, tapering towards apex, straight or slightly flexuous, smooth, brown to dark brown, unbranched, septate, $90-120 \mu \mathrm{m}(\bar{x}=105 \mu \mathrm{m}, \mathrm{SD}=15, \mathrm{n}=10)$ long, 7.5-8.5 $\mu \mathrm{m}(\bar{x}=8 \mu \mathrm{m}, \mathrm{SD}=0.5, \mathrm{n}=10)$ wide. Conidiogenous cells holoblastic, monoblastic, integrated, terminal, determinate, cylindrical or lageniform, smooth, mid to dark brown. Conidia acrogenous, solitary, dry, olivaceous brown to brown, pale at apex, obclavate, rostrate, smooth, straight or curved, truncate at base, 6-17euseptate, 77.5-108.5 $\mu \mathrm{m}(\bar{x}=93 \mu \mathrm{m}, \mathrm{SD}=15.5, \mathrm{n}=20)$ long, 17.5-20.5 $\mu \mathrm{m}(\bar{x}=19 \mu \mathrm{m}, \mathrm{SD}=1.5$, $\mathrm{n}=20$ ) wide.

Material examined - CHINA, Yunnan Province, Baoshan City, saprobic on decaying wood submerged in a stream in Gaoligong Mountain, July 2016, S.M. Tang, GS H 37-1, S-441, living culture, MFLUCC 16-1124.

Notes - Kirschsteiniothelia rostratas introduced by Hyde et al. (2017), was found on decaying wood submerged in a freshwater stream in Thailand. Morphologically, our fresh colletion fits well with $K$. rostrata, and the phylogenetic analysis showed that our isolate (MFLUCC 161124) clustered together with the ex-type culture (MFLUCC 15-0619) of K. rostrata (Fig. 1). Therefore we identified the fresh collection as $K$. rostrata and it is a new record for China.

\section{Discussion}

The genus Kirschsteiniothelia was introduced by Hawksworth (1985a) with K. aethiops (Berk. \& M.A. Curtis) D. Hawksw as the type species. Previous studies on Kirschsteiniothelia mostly reported on the sexual states (Hawksworth 1985a, Shearer 1993, Hyde et al. 1997, Chen et al. 2006, Mehrabi et al. 2017, Boonmee et al. 2012). Several asexual species of Kirschsteiniothelia are now known, viz. $K$. lignicola, $K$. emarceis, $K$. submersa, $K$. aethiops, $K$. tectonae and $K$. rostrata (Boonmee et al. 2012, Su et al. 2015, Li et al. 2016, Hyde et al. 2017). In this study, we provide descriptions and illustrations for four species of Kirschsteiniothelia and out of which three are new.

Most of the species of Kirschsteiniothelia are widespread in the tropics and usually found on dead wood in terrestrial habitats (Mehrabi et al. 2017). In this study, the fresh collections are from submerged wood in freshwater habitats of Yunnan Province, China. Kirschsteiniothelia rostrata was collected from Gaoligongshan Mountain, whereas $K$. aquatica was collected from Canshan Mountain, $K$. cangshanensis from the Jinsha River and $K$. fluminicola from the Dulong River in Yunnan, China. The results showed that Kirschsteiniothelia species are widely distributed in the western Yunnan Province of China.

Boonmee et al. (2012) established a new family Kirschsteiniotheliaceae to accommodate Kirschsteiniothelia sensu stricto in the class Dothideomycetes. However, on phylogenetic analysis, species of Kirschsteiniothelia are found polyphyletic and classified in Capnodiales, Jahnulales, Mytilinidiales and Pleosporales (Boonmee et al. 2012). Therefore, the placement of several Kirschsteiniothelia species remains uncertain based on morphology, until they are studied phylogenetically (Hawksworth 1985 a, b, Barr 1987, Lumbsch \& Lindemuth 2001, Wang et al. 2004, Vijaykrishna et al. 2006, Nelsen et al. 2009, Ruibal et al. 2009, Shearer et al. 2009). Hernandez-Restrepo et al. (2017) found that Kirschsteiniotheliaceae is distantly related to other lineages representing different orders in Dothideomycetes in their phylogenetic analysis. Therefore a new order Kirschsteiniotheliales was introduced to accommodate the family Kirschsteiniotheliaceae, with Kirschsteiniothelia as the type genus and this is followed in Wijayawardene et al. (2018).

Supplementary note - In the paper "Li WL, Luo ZL, Liu JK, Bhat DJ, Bao DF, Su HY, Hyde KD (2017) Lignicolous freshwater fungi from China I : Aquadictyospora lignicola gen. et sp. nov. and new record of Pseudodictyosporium wauense from northwestern Yunnan Province. Mycosphere 8(10), 1587-1597, Doi 10.5943/mycosphere/8/10/1", the "Material examined" and "Notes" for new species Aquadictyospora lignicola Z.L. Luo, W.L. Li, K.D. Hyde \& H.Y. Su are missed due to typographical errors. We therefore would add the "Material examined" and "Notes" for species Aquadictyospora lignicola here as follows: 
Material examined - CHINA, Yunnan Province, Dali, saprobic on decaying wood submerged in a stream in Cangshan Mountain, July 2016, H.Y. Su, 4XP H 2-9-3, (MFLU 17-1422, holotype), ex-type living culture MFLUCC 17-1318.
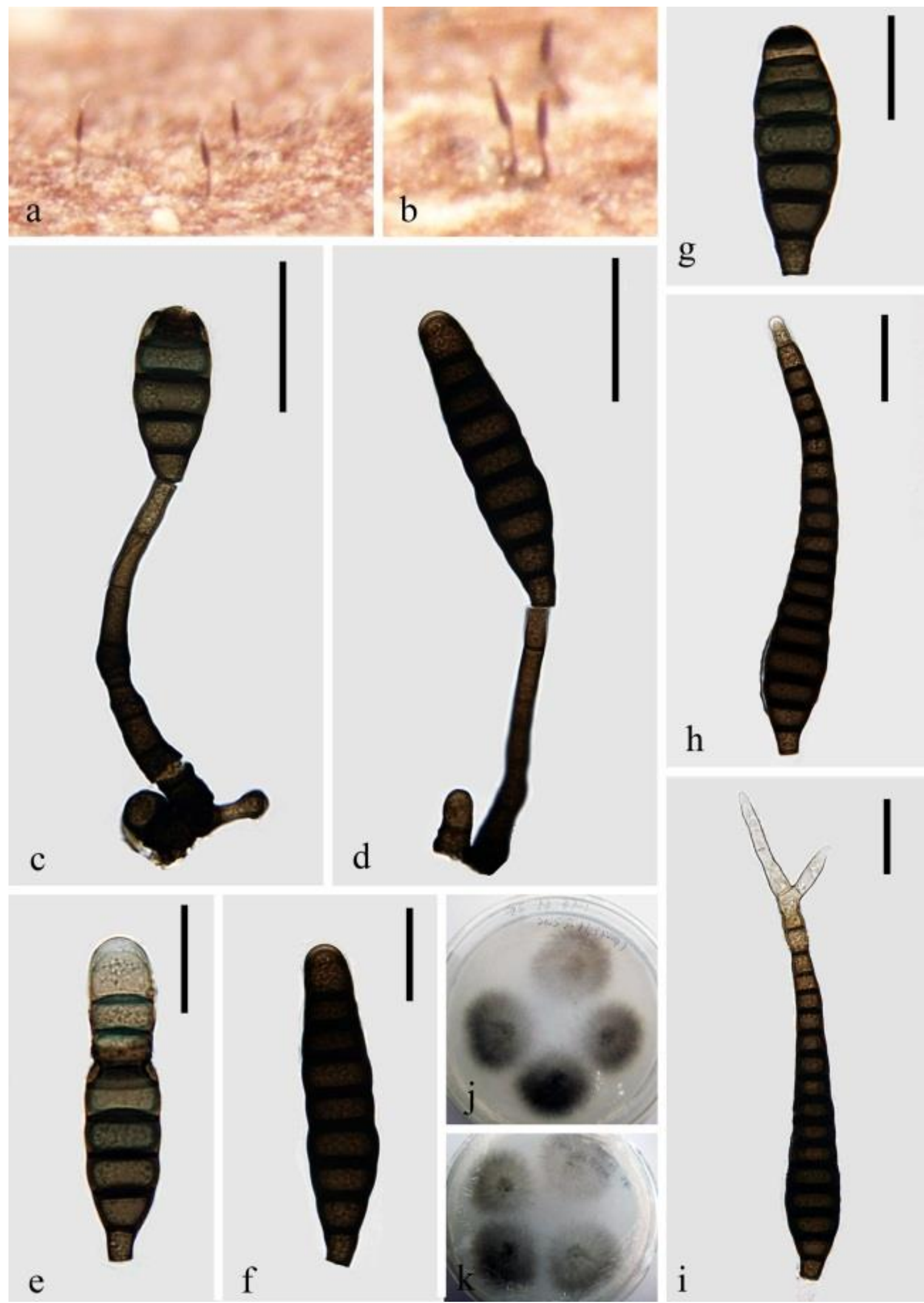

Figure 5 - Kirschsteiniothelia rostrata (GS H 37-1) a, b Colonies on wood. c, d Conidiophore with conidia. e-h Conidia. i Germinating conidium. j, k Culture on PDA from surface and reverse. Scale bars: $\mathrm{c}=30 \mu \mathrm{m}, \mathrm{d}=40 \mu \mathrm{m}, \mathrm{e}-\mathrm{i}=25 \mu \mathrm{m}$. 
Notes - Aquadictyospora is morphologically similar to Dictyocheirospora in having solitary, terminal, cheiroid and pale brown conidia. However, Aquadictyospora differs from the latter by its hyaline basal conidial cells. Aquadictyospora is comparable to the monotypic genus Bahugada K.A. Reddy \& V. Rao, typified by B. sundara K.A. Reddy \& V. Rao (Reddy \& Rao 1984), with its large hyaline basal cells in the conidia. Bahugada is distinguishable by its sparingly branched conidiophores and sympodial conidiogenous cells with broad denticles. The basal hyaline cell in Aquadictyospora is deeply constricted from above centre. The somewhat similar genera, Dictyosporium, Digitodesmium and Jalapriya, differ from Aquadictyospora in having conidia with appendages. The molecular phylogenetic study indicates its placement in Dictyosporiaceae as a genus which is phylogenetically related to the genera Aquaticheirospora, Dictyocheirospora, Digitodesmium, Jalapriya and Vikalpa.

\section{Acknowledgements}

We would like to thank the National Natural Science Foundation of China (Project ID: 31660008, 31460015) for financial and laboratory surpport. Zong-Long Luo thanks Shaun Pennycook from Landcare Research, Auckland, New Zealand, for advising on the taxon names. Jian-Kui Liu thanks the National Natural Science Foundation of China (NSFC 31600032) and Science and Technology Foundation of Guizhou Province (LH [2015]7061).

\section{References}

Barr ME. 1987 - Prodomus to class Loculoascomycetes. Publ. by the author, Amherst.

Barr ME. 1993 - Notes on the Pleomassariaceae. Mycotax on 49, 129-142.

Boonmee S, Koko TW, Chukeatirote E, Hyde KD et al. 2012 - Two new Kirschsteiniothelia species with Dendryphiopsis anamorphs cluster in Kirschsteiniotheliaceae fam. nov. Mycologia 104, 698-714.

Cai L, Jeewon R, Hyde KD. 2005 - Phylogenetic evaluation and taxonomic revision of Schizothecium based on ribosomal DNA and protein coding genes. Fungal Diversity 19, 1210.

Cai L, Jeewon R, Hyde KD. 2006 - Phylogenetic investigations of Sordariaceae based on multiple gene sequences and morphology. Mycological Research 110, 137-150.

Chen CY, Wang CL, Huang JW. 2006 - Two new species of Kirschsteiniothelia from Taiwan. Mycotaxon 98, 153-158.

Chomnunti P, Hongsanan S, Aguirre-Hudson B, Tian Q et al. 2014 - The sooty moulds. Fungal Diversity $66,1-36$.

Figueira D, Barata M. 2007 - Marine fungi from two sandy beaches in Portugal. Mycologia 99, 2023.

Glez-Peña D, Gómez-Blanco D, Reboiro-Jato M, Fdez-Riverola F et al. 2010 - ALTER: programoriented conversion of DNA and protein alignments. Nucleic Acids Research 38, 14-18.

Hawksworth DL. 1985a - Kirschsteiniothelia, a new genus for the Microthelia incrustans-group (Dothideales). Botanical Journal of the Linnean Sociely 91, 181-202.

Hawksworth DL. 1985b - A redisposition of the species referred to the ascomycete genus Microthelia. Bulletin of the British Museum for Natural History 14(2), 43-181.

Hernandez-Restrepo M, Gene J, Castaneda-Ruiz RF, Mena-Portales J et al. 2017 - Phylogeny of saprobic microfungi from Southern Europe. Studies in Mycology 86, 53-97.

Hughes SJ. 1953 - Conidiophores, conidia and classification. Canadian Journal of Botany 31, 577659.

Hyde KD. 1997 - Ascomycetes described on Freycinetia. Sydowia. 49(1), 1-20.

Hyde KD, Jones EBG, Liu JK, Ariyawansa H et al. 2013 - Families of Dothideomycetes. Fungal Diversity 63, 1-313. 
Hyde KD, Fryar S, Tian Q, Bahkali AH et al. 2016 - Lignicolous freshwater fungi along a northsouth latitudinal gradient in the Asian/Australian region; can we predict the affects of global warming on biodiversity and function? Fungal Ecology 19, 190-200.

Hyde KD, Norphanphoun C, Abreu VP, Bazzicalupo A et al. 2017 - Fungal diversity notes 603708: taxonomic and phylogenetic notes on genera and species. Fungal Diversity 87, 1-235.

Katoh K, Standley DM. 2013 - MAFFT multiple sequence alignment software version 7: improvements in performance and usability. Molecular Biology and Evolution 30, 772-780.

Kohlmeyer J, Kohlmeyer E. 1979 - Marine mycology: the higher Fungi. New York: Academic Press. 690.

Li GJ, Hyde KD, Zhao RL, Hongsanan S et al. 2016 - Fungal diversity notes 253-366: taxonomic and phylogenetic contributions to fungal taxa. Fungal Diversity 78, 1-237.

Li WL, Luo ZL, Liu JK, Bhat DJ et al. 2017 - Lignicolous freshwater fungi from China I : Aquadictyospora lignicola gen. et sp. nov. and new record of Pseudodictyosporium wauense from northwestern Yunnan Province. Mycosphere 8, 1587-1597.

Liu JK, Chomnunti P, Cai L, Phookamsak R et al. 2010 - Phylogeny and morphology of Neodeightonia palmicola sp. nov. from palms. Sydowia 62, 261-276.

Liu JK, Phookamsak R, Doilom M, Wikee S et al. 2012 - Towards a natural classification of Botryosphaeriales. Fungal Diversity 57, 149-210.

Lumbsch HT, Huhndorf SM, Lindemuth R. 2001 - Major lineages of Dothideomycetes (Ascomycota) inferred from SSU and LSU rDNA sequences. Mycological Research 105, 901908.

Luo ZL, Hyde KD, Liu JK, Bhat DJ et al. 2018 - Lignicolous freshwater fungi from China II: Novel Distoseptispora (Distoseptisporaceae) species from northwestern Yunnan Province and a suggested unified method for studying lignicolous freshwater fungi. Mycosphere 9(3), 444461.

Mehrabi M, Hemmati R, Asgari B. 2017 - Kirschsteiniothelia arasbaranica sp. nov., and an emendation of the Kirschsteiniotheliaceae. Cryptogamie Mycologie 38 (1), 13-25.

Miller MA, Pfeiffer W, Schwartz T. 2010 - Creating the CIPRES Science Gateway for inference of large phylogenetic trees. In: Proceedings of the 2010 Gateway Computing Environments Workshop (GCE), New Orleans, Louisiana, November 2010, 1-8.

Nelsen MP, Lücking R, Grube M, Mbatchou JS et al. 2009 - Unraveling the phylogenetic relationships of lichenized fungi in Dothideomyceta. Studies in Mycology 64, 135-144.

Nylander JAA. 2004 - MrModeltest v2 Program distributed by the author. Evolutionary Biology Centre, Uppsala University, Uppsala.

Rannala B, Yang Z. 1996 - Probability distribution of molecular evolutionary trees: a new method of phylogenetic inference. Journal of Molecular Evolution 43, 304-311.

Reddy KA, Rao V. 1984 - Bahugada-A new hyphomycetes. Current Science, 53, 542-544.

Ronquist F, Huelsenbeck JP. 2003 - MrBayes 3: Bayesian phylogenetic inference under mixed models. Bioinformatics 19(12), 1572.

Ruibal C, Gueidan C, Selbmann L, Gorbushina AA et al. 2009 - Phylogeny of rock-inhabiting fungi related to Dothideomycetes. Studies in Mycology 64, 123-133.

Schoch CL, Shoemaker RA, Seifert KA, Hambleton S et al. 2006 - A multigene phylogeny of the Dothideomycetes using four nuclear loci. Mycologia 98, 1041-1052.

Schoch CL, Crous PW, Groenewald JZ, Boehm EWA et al. 2009 - A classwide phylogenetic assessment of Dothideomycetes. Studies in Mycology 64, 1-15.

Shearer CA. 1993 - A new species of Kirschsteiniothelia (Pleosporales) with an unusual fissitunicate ascus. Mycologia 85(6), 963-969.

Shearer CA, Raja HA, Miller AN, Nelson P et al. 2009 - The molecular phylogeny of freshwater Dothideomycetes. Studies in Mycology 64, 145-153.

Shenoy BD, Jeewon R, Wu WP, Bhat DJ, Hyde KD. 2007 - Ribosomal and RPB2 DNA sequence analyses suggest that Sporidesmium and morphologically similar genera are polyphyletic. Mycological Research 110, 916-928 
Stamatakis A. 2006 - RAxML-VI-HPC: maximum likelihood-based phylogenetic analyses with thousands of taxa and mixed models. Bioinformatics 22(21), 2688-2690.

Stamatakis A, Hoover P, Rougemont J. 2008 - A rapid bootstrap algorithm for the RAxML web servers. Systematic Biology 57, 758-771.

Su HY, Udayanga D, Luo ZL, Manamgoda DS et al. 2015 - Hyphomycetes from aquatic habitats in Southern China: Species of Curvularia (Pleosporaceae) and Phragmocephala (Melanommataceae). Phytotaxa 226(3), 201-216.

Su HY, Hyde KD, Maharachchikumbura SSN, Ariyawansa HA et al. 2016 - The families Distoseptisporaceae fam. nov., Kirschsteiniotheliaceae, Sporormiaceae and Torulaceae, with new species from freshwater in Yunnan Province, China. Fungal Diversity 80, 375-409.

Suetrong S, Schoch CL, Spatafora JW, Kohlmeyer J et al. 2009 - Molecular systematics of the marine Dothideomycetes. Studies in Mycology 64, 155-173.

Vijaykrishna D, Jeewon R, Hyde KD. 2006 - Molecular taxonomy, origins and evolution of freshwater ascomycetes. Fungal Diversity 23, 351-390.

Wang YZ, Aptroot A, Hyde KD. 2004 - Revision of the Ascomycete genus Amphisphaeria. Fungal Diversity Research Series13, 1-168.

Wijayawardene NN, Crous PW, Kirk PM, Hawksworth DL et al. 2014 -Naming and outline of Dothideomycetes-2014 including proposals for the protection or suppression of generic names. Fungal Divers 69:1-55

Wijayawardene NN, Hyde KD, Rajeshkumar KC, Hawksworth DL et al. 2017a - Notes for genera: Ascomycota. Fungal Diversity 86, 1-594.

Wijayawardene NN, Hyde KD, Tibpromma S, Wanasinghe DN et al. 2017b - Towards incorporating asexual fungi in a natural classification: checklist and notes 2012-2016. Mycosphere 8, 1457-1554

Wijayawardene NN, Hyde KD, Lumbsch T, Liu JK et al. 2018 - Outline of Ascomycota - 2017. Fungal Diversity 88, 167-263. 